\title{
Lucidin Type Anthraquinone Glycosides from Putoria calabrica
}

\author{
İhsan Çaliş, ${ }^{*}, a$ Deniz Tasdemir, ${ }^{a}$ Chris M. Ireland, ${ }^{b}$ and Otto STicheR ${ }^{c}$ \\ ${ }^{a}$ Department of Pharmacognosy, Faculty of Pharmacy, Hacettepe University; TR-06100 Ankara, Turkey: ${ }^{b}$ Department of \\ Medicinal Chemistry, University of Utah; Salt Lake City, Utah 84112, U.S.A.: and ${ }^{c}$ Department of Applied BioSciences, \\ Institute of Pharmaceutical Sciences, Swiss Federal Institute of Technology (ETH) Zurich; CH-8057 Zürich, Switzerland. \\ Received January 11, 2002; accepted February 26, 2002
}

\begin{abstract}
Two new lucidin type anthraquinone glycosides, putorinoside A (1) and putorinoside B (2) were isolated from Putoria calabrica, in addition to two known anthraquinone glycosides, lucidin 3- $O$ - $\beta$-glucopyranoside (3) and lucidin 3-O-primeveroside (4). Based on spectroscopic data, putorinosides $A$ and $B$ were identified as 2-hydroxymethyl-1-methoxy-3,5,6-trihydroxyanthraquinone 3- $O$ - $\beta$-glucopyranoside and 2-hydroxymethyl-1-methoxy3,6-dihydroxyanthraquinone 3- $O$ - $\beta$-glucopyranoside, respectively.
\end{abstract}

Key words anthraquinone glycoside; lucidin-type anthraquinone; putorinosides A and B; Putoria calabrica; Rubiaceae

The Rubiaceae family is well known for containing anthraquinones. Our previous research on a Rubiaceaous plant, Putoria calabrica (L. fil) DC resulted in the isolation of iridoid, flavonoid and lignan glycosides. ${ }^{1,2)}$ Further investigation of the methanolic extract of the plant furnished four anthraquinone glycosides of lucidin type, 1-4. In this paper, we present the isolation and structure elucidation of the new compounds, 1 and 2.

Putorinoside A (1) was obtained as an amorphous red powder. The positive and negative ion electrospray ionization (ESI) mass spectra of $\mathbf{1}$ displayed the pseudomolecular ions, $[\mathrm{M}+\mathrm{Na}]^{+}$and $[\mathrm{M}-\mathrm{H}]^{-}$at $m / z 501$ and 477, respectively. The molecular formula of $\mathrm{C}_{22} \mathrm{H}_{22} \mathrm{O}_{12}$ was derived from high resolution (HR)-FAB-MS $\quad\left([\mathrm{M}+\mathrm{H}]^{+}, \quad m / z \quad 479.1183\right.$, $\Delta=0.7 \mathrm{mmu}$ ). An unsaturation number of 12 , deduced from the MS and ${ }^{13} \mathrm{C}-\mathrm{NMR}$ data (Table 1 ), suggested the presence of four rings. The UV spectrum of $\mathbf{1}$ showed absorption bands at $\lambda_{\max } 268,304$ (sh), 345 and $432 \mathrm{~nm}$, indicative of an anthraquinone structure. 1 further displayed IR bands at $v_{\max }$ 3400 (broad), 1668 and $1641 \mathrm{~cm}^{-1}$ for hydroxyl group(s) and unchelated and chelated carbonyl functions, respectively. The ${ }^{13} \mathrm{C}$-NMR spectrum (DMSO- $d_{6}$, Table 1 ) contained signals for all 22 carbons. Sixteen signals were accounted for by the anthraquinone aglycone, among them four signals belonging to aromatic carbons bearing an oxygen atom $(\delta 150.0,151.5$, $160.4,160.6)$, two signals belonging to a $p$-quinone moiety ( $\delta 179.0,187.9)$, and two belonging to oxygenated aliphatic carbons $(\delta 51.9,62.6)$. The distortionless enhancement by polarization transfer (DEPT)-135 experiment indicated that the latter signals were due to an oxymethylene $(\delta 51.9 \mathrm{t})$ and a methoxyl ( $\delta 62.6$ q) group. Also present were signals belonging to the six carbons of a hexose unit within $\mathbf{1}$. All these data revealed that $\mathbf{1}$ was an anthraquinone glycoside with two hydroxy, one methoxy and one oxymethylene substituents. The ${ }^{1} \mathrm{H}-\mathrm{NMR}$ spectrum (Table 1 , DMSO- $d_{6}$ ) contained, for the aglycone moiety, two doublets at $\delta 7.20$ and 7.58 (each representing $1 \mathrm{H}, J=8.0 \mathrm{~Hz}$ ), an aromatic proton singlet at $\delta$ $7.75(1 \mathrm{H})$, a complex multiplet of $2 \mathrm{H}$ at $\delta 4.60$, a methoxy function $(\delta 3.82)$ and two $\mathrm{D}_{2} \mathrm{O}$-exchangeable protons (broad, $\mathrm{OH})$ at $\delta 10.6$ and $\delta 12.4$. The sugar moiety demonstrated an anomeric proton signal at $\delta 5.10$ as a doublet $(J=7.8 \mathrm{~Hz})$, four overlapping protons between $\delta 3.24-3.40$ and an oxymethylene group at $\delta 3.53(\mathrm{dd}, J=4.5,11.0 \mathrm{~Hz})$ and 3.70 (dd, $J=2.0,11.0 \mathrm{~Hz}$ ). From this data, associated with the ${ }^{13} \mathrm{C}$ -
NMR data, it was obvious that the sugar unit was $\beta$-glucopyranose. The site of glycosylation and the substitution pattern of the anthraquinone aglycone could be deduced by twodimensional (2D)-NMR experiments, particularly by gradient heteronuclear multiple bond connectivity (gHMBC). The methoxy protons exhibited a long range coupling with $\mathrm{C}-1(\delta$ $160.6 \mathrm{~s}$ ) of ring $\mathrm{C}$, confirming its location on this carbon atom. Likewise, the long distance correlations from $\mathrm{H}_{2}-15(\delta$ $4.60 \mathrm{~m})$ to $\mathrm{C}-2(\delta 121.1 \mathrm{~s})$ and $\mathrm{C}-3(\delta 160.4 \mathrm{~s})$ served to position the hydroxymethyl function at $\mathrm{C}-2$. Upon observation of a prominent $\mathrm{HMBC}$ cross peak between the anomeric proton $\left(\delta 5.10, \mathrm{H}-1^{\prime}\right)$ and $\mathrm{C}-3$, the site of glycosylation was predicted to be at $\mathrm{C}-3$. This interpretation was confirmed by further HMBC correlations between $\mathrm{H}_{2}-15 / \mathrm{C}-3$ and $\mathrm{H}-4 / \mathrm{C}-3$. Thus, the isolated aromatic proton signal at $\delta 7.75$ (s) was ascribed to C-4. The ${ }^{2} J_{\mathrm{CH}}$ and ${ }^{3} J_{\mathrm{CH}}$ correlations obtained from $\mathrm{H}-4$ to $\mathrm{C}-2, \mathrm{C}-10, \mathrm{C}-13$ and $\mathrm{C}-14$ unambigiously proved this assignment. The $\mathrm{C}-10$ carbonyl carbon $(\delta$ 187.9) was deshielded by $c a .9$ ppm compared to that of C-9 ( $\delta 179.0)$, suggesting strong hydrogen bonding with a phenolic hydroxyl group. ${ }^{3,4)}$ Thus, C-5 ( $\delta$ 150.0) was recognized to bear a peri-hydroxyl function to $\mathrm{C}-10$ carbonyl. The chemical shift of one of the exchangeable protons $(\delta 12.4$, br s) further corroborated this suggestion. ${ }^{3,4)}$ Since two aromatic signals at $\delta 7.20(\mathrm{H}-7)$ and $\delta 7.58(\mathrm{H}-8)$ coupled with the coupling constant of $J_{\mathrm{AB}}=8.0 \mathrm{~Hz}$, they had to be ortho positioned, and thus, the second phenolic hydroxyl group ( $\delta 10.6$, brs, exchangeable) had to reside at C-6 $(\delta$ 151.5). This substitution was confirmed by ${ }^{1} \mathrm{H}-{ }^{1} \mathrm{H}$ correlation spectroscopy (COSY) couplings, and ${ }^{1} \mathrm{H}-{ }^{13} \mathrm{C}$ long range correlations $\left({ }^{3} J_{\mathrm{CH}}\right)$ between $\mathrm{H}-7 / \mathrm{C}-5, \mathrm{H}-7 / \mathrm{C}-12$ and H-8/C-6, H-8/C-9. Based upon these evidences, 1 was determined to be a new anthraquinone glycoside, 2-hydroxymethyl-1-methoxy-3,5,6-trihydroxyanthraquinone $3-O$ - $\beta$-glucopyranoside.

Putorinoside B (2) was obtained as an amorphous orange powder. The positive and negative ion ESI mass spectra of $\mathbf{2}$ exhibited the pseudomolecular ions, $[\mathrm{M}+\mathrm{Na}]^{+}$and $[\mathrm{M}-\mathrm{H}]^{-}$ at $\mathrm{m} / \mathrm{z} 485$ and 461, respectively. The molecular formula, $\mathrm{C}_{22} \mathrm{H}_{22} \mathrm{O}_{11}(m / z 463.1219,16$ amu less than that of $\mathbf{1})$, was established by positive HR-FAB-MS and ${ }^{13} \mathrm{C}-\mathrm{NMR}$ spectra (Table 1). Many of the carbon and proton resonances of 2 were almost identical to those of $\mathbf{1}$, implying a close similarity in their structures. Significant differences between $\mathbf{1}$ and $\mathbf{2}$ in the ${ }^{1} \mathrm{H}$ - and ${ }^{13} \mathrm{C}-\mathrm{NMR}$ spectra (Table 2) were restricted to 
Table 1. ${ }^{1} \mathrm{H}-(500 \mathrm{MHz})$ and ${ }^{13} \mathrm{C}-\mathrm{NMR}(125 \mathrm{MHz})$ Data of $\mathbf{1}$ and 2 (DMSO- $d_{6} ; \delta$ in ppm, $J$ in $\mathrm{Hz}$ ).

\begin{tabular}{|c|c|c|c|c|}
\hline \multirow{2}{*}{$\mathrm{C} / \mathrm{H}$ atom } & \multicolumn{2}{|l|}{1} & \multicolumn{2}{|l|}{2} \\
\hline & $\delta_{\mathrm{H}}$ & $\delta_{\mathrm{C}}$ & $\delta_{\mathrm{H}}$ & $\delta_{\mathrm{C}}$ \\
\hline 1 & & $160.6 \mathrm{~s}$ & & $160.4 \mathrm{~s}$ \\
\hline 2 & & $121.1 \mathrm{~s}$ & & $120.4 \mathrm{~s}$ \\
\hline 3 & & $160.4 \mathrm{~s}$ & & $160.5 \mathrm{~s}$ \\
\hline 4 & $7.75 \mathrm{~s}$ & $108.9 \mathrm{~d}$ & $7.69 \mathrm{~s}$ & $109.1 \mathrm{~d}$ \\
\hline 5 & & $150.0 \mathrm{~s}$ & 7.41 brs & $111.5 \mathrm{~d}$ \\
\hline 6 & & $151.5 \mathrm{~s}$ & & $162.6 \mathrm{~s}$ \\
\hline 7 & $7.20 \mathrm{~d}(8.0)$ & $120.8 \mathrm{~d}$ & $7.21 \mathrm{brd}(8.0)$ & $121.9 \mathrm{~d}$ \\
\hline 8 & $7.58 \mathrm{~d}(8.0)$ & $120.6 \mathrm{~d}$ & $8.02 \mathrm{~d}(8.0)$ & $129.7 \mathrm{~d}$ \\
\hline 9 & & $179.0 \mathrm{~s}$ & & $179.6 \mathrm{~s}$ \\
\hline 10 & & $187.9 \mathrm{~s}$ & & $182.3 \mathrm{~s}$ \\
\hline 11 & & $115.7 \mathrm{~s}$ & & $134.0 \mathrm{~s}$ \\
\hline 12 & & $125.2 \mathrm{~s}$ & & $125.3 \mathrm{~s}$ \\
\hline 13 & & $135.5 \mathrm{~s}$ & & $135.8 \mathrm{~s}$ \\
\hline 14 & & $132.2 \mathrm{~s}$ & & $131.7 \mathrm{~s}$ \\
\hline 15 & $4.60 \mathrm{~m}$ & $51.9 \mathrm{t}$ & $\begin{array}{l}4.64 \mathrm{~d}(11.0) \\
4.56 \mathrm{~d}(11.0)\end{array}$ & $52.0 \mathrm{t}$ \\
\hline $1^{\prime}$ & $5.10 \mathrm{~d}(7.8)$ & $101.1 \mathrm{~d}$ & $5.06 \mathrm{~d}(7.8)$ & $101.1 \mathrm{~d}$ \\
\hline $2^{\prime}$ & $3.37^{a)}$ & $73.3 \mathrm{~d}$ & $3.36^{a)}$ & $73.3 \mathrm{~d}$ \\
\hline $3^{\prime}$ & $3.34^{a)}$ & $76.0 \mathrm{~d}$ & $3.34^{a)}$ & $76.0 \mathrm{~d}$ \\
\hline $4^{\prime}$ & $3.24^{a)}$ & $69.4 \mathrm{~d}$ & $3.25^{a)}$ & $69.4 \mathrm{~d}$ \\
\hline $5^{\prime}$ & $3.40^{a)}$ & $77.4 \mathrm{~d}$ & $3.41^{a)}$ & $77.3 \mathrm{~d}$ \\
\hline $6^{\prime}$ & $\begin{array}{l}3.53 \mathrm{dd}(11.0,4.5) \\
3.70 \mathrm{dd}(11.0 .2 .0)\end{array}$ & $60.5 \mathrm{t}$ & $\begin{array}{l}3.54 \mathrm{dd}(5.0,11.0) \\
3.71 \mathrm{brd}(11.0)\end{array}$ & $60.5 \mathrm{t}$ \\
\hline $\mathrm{OCH}_{3}$ & $3.82 \mathrm{~s}$ & $62.6 \mathrm{q}$ & $3.83 \mathrm{~s}$ & $62.7 \mathrm{q}$ \\
\hline $5-\mathrm{OH}$ & $12.4 \mathrm{br} \mathrm{s}$ & & & \\
\hline $6-\mathrm{OH}$ & $10.6 \mathrm{brs}$ & & & \\
\hline
\end{tabular}

a) Multiplicity is unclear due to overlapping.

the ring $\mathrm{A}$, where one of the phenolic hydroxy groups was replaced by an aromatic proton signal $\left(\delta_{\mathrm{H}} 7.41 \mathrm{brs}, \delta_{\mathrm{C}} 115.1\right.$ d). The upfield shift of the C-10 carbonyl function $(\delta 182.3)$ in conjunction with the IR data $\left(1668 \mathrm{~cm}^{-1}\right.$, unchelated carbonyl function) suggested that the peri-hydroxy group (C-5) in 1 was absent in 2. Three bond $\mathrm{HMBC}$ couplings between the pairs H-5/C-7, H-5/C-10; H-7/C-5, H-7/C-12; and H-8/C$6, \mathrm{H}-8 / \mathrm{C}-9$ further supported the presence of only one $\mathrm{OH}$ function in ring A, namely at C-6 $(\delta$ 162.6). Detailed inspection of the gHSQC, DQF-COSY, and gHMBC data (Fig. 1) substantiated the structure of $\mathbf{2}$ as shown. Compound $\mathbf{2}$ is 2hydroxymethyl-1-methoxy-3,6-dihydroxyanthraquinone 3-O$\beta$-glucopyranoside.

The spectroscopic data for the known glycosides, lucidin 3-O- $\beta$-glucopyranoside (3) and lucidin 3-O-primeveroside (4), showed good accordance to those of previously reported. ${ }^{5}$ )

\section{Experimental}

General Experimental Procedures and Plant Material As reported in previous study. ${ }^{2)}$

Extraction and Isolation The air-dried and powdered plant material $(90 \mathrm{~g})$ was extracted with $\mathrm{MeOH}(500 \mathrm{ml} \times 2)$ for $6 \mathrm{~h}$ at $45^{\circ} \mathrm{C}$ and filtered. The filtrate was concentrated to dryness in vacuo. The resulting residue was dissolved in $\mathrm{H}_{2} \mathrm{O}$ and partitioned with $\mathrm{CHCl}_{3}$. The $\mathrm{H}_{2} \mathrm{O}$ phase was lyophilized $(15 \mathrm{~g}$, yield $15 \%)$ and preadsorbed onto $\mathrm{SiO}_{2}(25 \mathrm{~g})$. This mixture was applied to a Si gel column $(250 \mathrm{~g})$ using the mixture of $\mathrm{CH}_{2} \mathrm{Cl}_{2}-$ $\mathrm{MeOH}-\mathrm{H}_{2} \mathrm{O}(80: 20: 1,80: 20: 2,70: 30: 3)$ to give 150 fractions which were combined into nine fractions, $\mathrm{A}-\mathrm{J}$. The isolation studies on the fractions D, E, F, G, I, and J afforded iridoid, lignan and flavonoid glycosides. ${ }^{2)}$ The subfractions E1, G2-G3 and J2, remained after the isolation of these compounds, were subjected to repeated chromatography on Sephadex LH$20(\mathrm{MeOH})$ and $\mathrm{C}_{18}$-MPLC $\left(0\right.$ to $70 \% \mathrm{MeOH}$ in $\mathrm{H}_{2} \mathrm{O}$ ) to afford lucidin 3-O$\beta$-glucopyranoside $(3,7 \mathrm{mg})$, putorinoside $\mathrm{B}(\mathbf{2}, 11 \mathrm{mg})$, lucidin $3-O-$
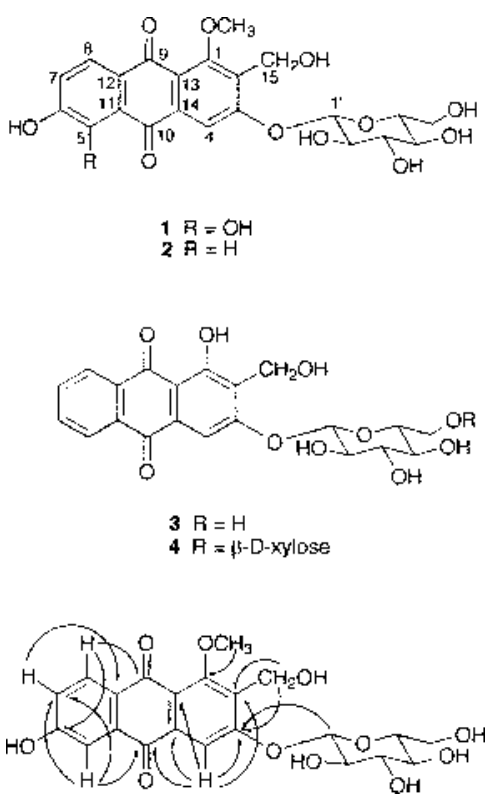

Fig. 1. Observed HMBC Correlations for Putorinoside B (2)

primeveroside $(4,33 \mathrm{mg})$, and putorinoside $\mathrm{A}(1,130 \mathrm{mg})$, respectively.

Putorinoside A (1): ${ }^{1} \mathrm{H}-\mathrm{NMR}\left(500 \mathrm{MHz}, \mathrm{DMSO}-d_{6}\right.$, Table 1$),{ }^{1} \mathrm{H}-\mathrm{NMR}$ $\left(500 \mathrm{MHz}, \mathrm{CD}_{3} \mathrm{OD}\right): \delta 3.40-3.59\left(4 \mathrm{H}, \mathrm{H}-2^{\prime}-\mathrm{H}^{\prime} 5^{\prime}\right), 3.73(1 \mathrm{H}, \mathrm{dd}, J=4.0$, $\left.11.0 \mathrm{~Hz}, \mathrm{H}-6^{\prime} \mathrm{a}\right), 3.90$ ( $1 \mathrm{H}, \mathrm{br}$ d, $\left.J=11.0 \mathrm{~Hz}, \mathrm{H}-6^{\prime} \mathrm{b}\right), 3.86$ (3H, s, OMe), 4.70 (d, $J=11.0 \mathrm{~Hz}, \mathrm{H}-15 \mathrm{a}), 4.73(\mathrm{~d}, J=11.0 \mathrm{~Hz}, \mathrm{H}-15 \mathrm{~b}), 5.14(\mathrm{~d}, J=7.8 \mathrm{~Hz}, \mathrm{H}-$ $\left.1^{\prime}\right), 7.20(\mathrm{~d}, J=8.0 \mathrm{~Hz}, \mathrm{H}-7), 7.60$ (d, $\left.J=8.0 \mathrm{~Hz}, \mathrm{H}-8\right), 7.80(\mathrm{~s}, \mathrm{H}-4) .{ }^{13} \mathrm{C}-$ NMR (125 MHz, DMSO- $d_{6}$, Table 1), ${ }^{13} \mathrm{C}$-NMR (125 MHz, $\left.\mathrm{CD}_{3} \mathrm{OD}\right): \delta 53.8$ (t, C-15), 62.3 (t, C-6'), 63.6 (q, OMe), 71.1 (d, C-4'), 74.9 (d, C-2'), 77.8 (d, C-3'), 78.5 (d, C-5'), 102.4 (d, C-1'), 110.7 (d, C-4), 116.9 (s, C-11), 122.2 (d, C-8), 122.3 (d, C-7), 122.6 (s, C-2), 126.6 (s, C-12), 132.9 (s, C14), 137.6 (s, C-13), 151.6 (s, C-5), 153.8 (s, C-6), 162.1 (s, C-1), 162.4 (s, C-3), 181.4 (s, C-9), 188.4 (s, C-10). UV (MeOH) $\lambda_{\max } 268,304$ (sh), 345, and $432 \mathrm{~nm}$. IR $(\mathrm{KBr}) v_{\max } 3400(\mathrm{OH}), 1668$ (unchelated $\left.\mathrm{C}=\mathrm{O}\right), 1641$ (chelated $\mathrm{C}=\mathrm{O}$ ), and $1585 \mathrm{~cm}^{-1}$ (aromatic ring). Negative ion ESI-MS $\mathrm{m} / z$ $477[\mathrm{M}-\mathrm{H}]^{-}, 315[\mathrm{M}-163]^{-}$and $299[\mathrm{M}-163-14]^{-}$. Positive ion ESI-MS $m / z 501[\mathrm{M}+\mathrm{Na}]^{+}, 479[\mathrm{M}+\mathrm{H}]^{+}, 317[\mathrm{M}-162+\mathrm{H}]^{+}$. Positive FAB-MS $\mathrm{m} / \mathrm{z} 479[\mathrm{M}+\mathrm{H}]^{+}$, HR-FAB-MS $\mathrm{m} / z$ Obsd 479.1183 for $[\mathrm{M}+\mathrm{H}]^{+}$, Calcd for $\mathrm{C}_{22} \mathrm{H}_{23} \mathrm{O}_{12} 479.1190 .[\alpha]_{\mathrm{D}}^{20}-96^{\circ}(c=0.05, \mathrm{MeOH})$.

Putorinoside B (2): ${ }^{1} \mathrm{H}-\mathrm{NMR}\left(500 \mathrm{MHz}\right.$, DMSO- $d_{6}$, Table 1$),{ }^{1} \mathrm{H}-\mathrm{NMR}$ $\left(500 \mathrm{MHz}, \mathrm{CD}_{3} \mathrm{OD}\right): \delta 3.45-3.65\left(4 \mathrm{H}, \mathrm{H}-2^{\prime}-\mathrm{H}-5^{\prime}\right), 3.79(1 \mathrm{H}, \mathrm{dd}, J=5.0$, $\left.12.0 \mathrm{~Hz}, \mathrm{H}-6^{\prime} \mathrm{a}\right), 3.92$ (3H, s, OMe), $3.94\left(1 \mathrm{H}, \mathrm{dd}, J=2.5,12.0 \mathrm{~Hz}, \mathrm{H}-6^{\prime} \mathrm{b}\right)$, 4.73 (d, $J=11.4 \mathrm{~Hz}, \mathrm{H}-15 \mathrm{a}), 4.82$ (d, $J=11.4 \mathrm{~Hz}, \mathrm{H}-15 \mathrm{~b}), 5.18$ (d, $J=7.8 \mathrm{~Hz}$, H-1'), 7.11 (dd, $J=2.0,8.4 \mathrm{~Hz}, \mathrm{H}-7$ ), 7.40 (br s, H-5), 7.80 (s, H-4), 8.04 (d, $J=8.4 \mathrm{~Hz}, \mathrm{H}-8) ;{ }^{13} \mathrm{C}-\mathrm{NMR}\left(125 \mathrm{MHz}, \mathrm{DMSO}-d_{6}\right.$, Table 1$)$. UV $(\mathrm{MeOH})$ $\lambda_{\max } 216,274,338$ and $416 \mathrm{~nm}$. IR (KBr) $v_{\max } 3400(\mathrm{OH}), 1668$ (unchelated $\mathrm{C}=\mathrm{O}$ ) and $1580 \mathrm{~cm}^{-1}$ (aromatic ring); Negative ion ESI-MS $\mathrm{m} / \mathrm{z} 461$ $[\mathrm{M}-\mathrm{H}]^{-}, 299[\mathrm{M}-163]^{-}$. Positive ion ESI-MS $\mathrm{m} / z 485[\mathrm{M}+\mathrm{Na}]^{+}$. Positive FAB-MS $m / z 463[\mathrm{M}+\mathrm{H}]^{+}$, HR-FAB-MS $m / z$ Obsd 463.1219 for $[\mathrm{M}+\mathrm{H}]^{+}$, Calcd for $\mathrm{C}_{22} \mathrm{H}_{23} \mathrm{O}_{11} 463.1240$. $[\alpha]_{\mathrm{D}}^{20}-56^{\circ}(c=0.05, \mathrm{MeOH})$.

Acknowledgments The authors thank Prof. Dr. Zeki Aytac, Gazi University, for the authentification of the plant specimen. We are grateful to Dr. Elliot Rachlin and Dr. Vajira Nanayakkara, University of Utah, for performing mass spectra.

\section{References}

1) Linden A., Çalış İ., Neuburger M., Sticher O., Acta Cryst., C56, 616618 (2000).

2) Çalış İ., Heilmann J., Tasdemir D., Linden A., Ireland C. M., Sticher O., J. Nat. Prod., 64, 961-964 (2001).

3) Banthorpe D. V., White J. J., Phytochemistry, 38, 107-111 (1995).

4) Schripsema J., Dagnino D., Phytochemistry, 42, 177-184 (1996).

5) El-Emary N. A., Backheet E. Y., Phytochemistry, 49, 277-279 (1998). 